\title{
Estimation of the J-curve in China: a cointegration approach
}

\author{
Jaleel Ahmad $^{*}$ and Jing Yang ${ }^{* *}$
}

\begin{abstract}
This paper investigates whether a J-curve can be detected in the time series data on China's bilateral trade with the G-7 countries. It utilizes cointegration and causality tests to ascertain both the long-run relatedness, and the short-run dynamics, between the real exchange rate, national income, and the trade balance. There is some evidence that a real depreciation eventually improves the trade balance with some countries. But there is no indication of a negative short-run response which characterizes the J-curve.
\end{abstract}

Keyword: China Trade Balance, J-curve, measurement by cointegration, error correction models, significance tests.

\section{Introduction}

The process of adjustment in trade balance following a currency devaluation is believed to exhibit three distinct phases. The trade balance initially worsens due to "perverse valuation", as domestic currency prices of imports rise. The balance gradually improves as demand elasticities of exports and imports approach their long-run values, and finally surpasses its initial level after the Marshall-Lerner condition is satisfied. The initial worsening of the trade balance before its eventual improvement is what is commonly described as the J-curve. The J-curve cannot be dismissed as a mere empirical quirk. It is known to play an important role in the interpretation of

*Corresponding author; Professor, Department of Economics, Concordia University, 1455 Blvd de Maisonneuve, Montreal, Qc Canada H3G 1M8. Tel.+1-514-848-2424, ext. 3921;+1-514-845-7586, E-mail: ahmj@alcor.concordia.ca

${ }^{*}$ Ph. D. Candidate, Department of Economics, Concordia University, 1455 Blvd de Maisonneuve, Montreal, Qc Canada H3G 1M8 
the Mundell-Fleming model and can radically alter its predictions (Niehans 1975). Moreover, a devaluation in the presence of a J-curve may have more than a perverse effect on the trade balance; it can have a deflationary effect on the economy and may also produce more short-run inflation (Dornbusch and Krugman 1976). Consequently monetary and fiscal policies for stabilization must deal with additional problems of foreign exchange market instability (Ueda 1983).

Given the implications of the J-curve for the conduct of macroeconomic stabilization policies, its empirical estimation has been a subject of interest (see, Bahmani - Oskooee and Ratha 2004). A number of studies have estimated the effect of a change in the real exchange rate on the balance of trade and have confirmed the existence of the J-curve (Artus 1978, Miles 1979, Spitaller 1980, Helkie and Hooper 1987, Krugman and Baldwin 1987, and Marwah and Klein 1996). However, Rose and Yellen (1989), using the data on the U.S. bilateral trade with the G-7 countries as well as the aggregate U.S. trade, did not find any statistically significant evidence for the J-curve. Rose and Yellen's findings are important because theirs is the first time series econometric study that refutes the empirical validity of the J-curve.

The purpose of this paper is to reexamine the empirical validity of the J-curve by using the time series data on China's bilateral trade with the G-7 countries. A basic motivation for our empirical exercise is to use cointegration methodologies for estimating the J-curve directly from a reduced form equation, rather than from a detailed structural model, as explained in footnote 2. We utilize the unit root and cointegration methodologies to investigate the issues arising from nonstationarity of the data, the degree of differencing, and the long-run equilibrium relationship between real exchange rate, national income in the home and partner countries, and the trade balance. Since trade elasticities of a country may vary across its trading partners, the process of trade balance adjustment following a change in relative prices as a result of devaluation needs to be bilaterally decomposed. As a major developing country with a number of devaluation episodes in the recent past and a sizable volume of trade, the estimation of J-curve from the Chinese data should prove to be instructive.

The rest of the paper is organized as follows. The next section contains a brief description of exchange rate devaluation and price movements following China's economic reforms. Section III outlines the basic econometric model used in this study to test for the existence of the J-curve. This section also describes the estimation procedure and sources of data. The main empirical results are reported in Section IV. Section V highlights the major conclusions.

\section{Some basic facts}

China's economic reforms began in December 1978. The reforms of foreign trade, foreign investment, and of the financial system have played a pivotal role in China's move toward a market economy. The monopoly of foreign trade by state trading corporations (STC) was broken up in 1979 and the conduct of foreign trade was transferred to a decentralized group of provincial and regional corporations. This was the major factor which led to a gradual breakdown of the "air lock" between domestic enterprises and foreign markets, as international prices began to pass 
through to a liberalized domestic market. The reform package also included a reduction in import tariffs and a replacement of a number of quantitative restrictions (QRs) by tariffs (Lardy 1992). As a result, imports grew at such a rapid rate (by 44 per cent in 1979-80 period alone) that China found itself faced with a growing trade deficit.

As part of the reform package that included export subsidies, the Yuan was devalued from 1.7 to the U.S. dollar in 1981 to 2.9 in 1985, and again to 4.8 in 1986 . This represented a 182 per cent rise in the exchange rate over a 4-year period and, according to Perkins (1994), was much larger in magnitude than the 87 per cent rise in China's retail prices. Since the reform process began 17 years ago the size of China's economy has quadrupled, with real output increasing at 9 per cent annually (Zhang 1999). The surge in demand which was accommodated by expansionary monetary policies caused inflationary pressures to intensify during 1992-93. As the liberalization process gathered speed, monetary policy faced serious difficulties in the context of growing external surpluses and inadequate monetary instruments (IMF 1995).

A 15-point reform package launched in mid 1993 ended the dichotomy between the official and market exchange rates of the Yuan to the U.S. dollar. The Yuan depreciated further to 8.4 to the U.S. dollar at the end of 1994, culminating in a rise of the exchange rate of 450 per cent over a 14-year period. The "real" depreciation would be considerably less than this, but would still be large enough to warrant a significant change in the trade balance. Even though the period covered in our study contains residual elements of distortion arising from state controls and multiple exchange rates (which weaken the exchange rate's ability to link domestic and foreign prices), the question of whether the trade balance is responsive to a sizable change in the exchange rate is worth a closer look.

China's exchange rate and its external imbalance has aroused much controversy. Goldstein (2007), and Goldstein and Lardy (2006) among others, provide a detailed picture of the presumed underevaluation of the Renminbi and of policies needed to correct the imbalance. On the one hand, the current estimates of underevaluation are disputed (e.g., Wein, 1999, Cheung, Chinn and Fujii 2007, and Wilson 2001, among others). A similar conclusion with respect to Renminbi and other East Asian currencies, i.e., an absence of significant undervaluation, is advanced in a number of studies in Mckinnon (2005). In any event, the currency underevaluation, and the absence of a consumption - driven growth path in China, are issues outside the scope of this paper and are not pursued here.

\section{The model, methodology and the data}

Our model specification closely follows that of Rose and Yellen (1989) with some differences in methodology. Trade balance can be written as a partially reduced functional form:

$$
\mathrm{B}=\mathrm{B}\left(\mathrm{q}, \mathrm{Y}, \mathrm{Y}^{*}\right)
$$

where B is the home country's balance of trade in real terms, $q$ is the real exchange rate, and Y and 
$\mathrm{Y}^{*}$ are levels of real income measured in domestic and foreign output, respectively. ${ }^{1}$ The real exchange rate is defined as $\mathrm{q}=\mathrm{E} /\left(\mathrm{P} / \mathrm{P}^{*}\right)$ or $\mathrm{E} \cdot \mathrm{P}^{*} / \mathrm{P}$ where $\mathrm{E}$ is the nominal exchange rate, i.e., the domestic price of foreign currency, and $\mathrm{P}$ and $\mathrm{P}^{*}$ are domestic and foreign price levels, respectively.

The estimated regression equations (2) through (4) described in the section on "Econometric Methodology" below are log-linear approximations of (1), except the trade balance, and include a constant, a number of lags, and an error term. ${ }^{2}$

\subsection{The data}

Most previous research on J-curve has used aggregate trade data for the devaluing country's trade balance with the rest-of-the-world (ROW). While it is easier to estimate the change in trade balance with respect to a country's global trade, it poses difficult problems of constructing a meaningful real exchange rate index and proxies for the ROW real income. Moreover, since trade elasticities are likely to vary across trading partners, the effect of real exchange rate on the trade balance should be bilaterally decomposed for a more precise estimate.

The analysis in this paper utilizes a 26-year series of quarterly data on bilateral trade between the Peoples Republic of China and the Group of Seven (G-7) countries, viz., the United States, Canada, Japan, France, Germany, Italy, and the United Kingdom. The basic source of this data is the International Monetary Fund, Direction of Trade Statistics (various years), which gives the value of China's merchandise exports and imports for each of the G-7 countries in nominal U.S. dollars. The real net trade balance is obtained by taking the difference between exports and imports and deflating it by the U.S. GDP deflator. The data on nominal exchange rates, the GDP, the price levels, and GDP deflators are all from the International Financial Statistics Yearbook (various years) published by the International Monetary Fund (IMF). Since quarterly data on China's trade balance is not available for all G-7 countries, our decision to decompose trade balance bilaterally constrained us to use annual data for the period 1974 through 2000 for some G-7 countries. For China's trade with the U.S. and Canada, we provide estimates using both annual and quarterly data.

\subsection{Econometric methodology}

In using time series data the first essential diagnostic step is to test for the stationarity of the variables. This is necessary to avoid the problem of "spurious regression", as argued in Granger and Newbold (1974). Most previous studies on J-curve have used level data without testing for

\footnotetext{
${ }^{1} \mathrm{~A}$ similar functional form has been used in all other studies that have estimated the J-curve.

${ }^{2}$ All conventional studies estimate the impact of real exchange rate on trade balance by estimating a set of structural equations for exports and imports in terms of their volume and pass-through of exchange rate changes. Rose and Yellen (1989) have demonstrated that a direct estimation of (1) is preferable to the more detailed structural approach prevalent in the empirical literature on J-curve. The reason is that the dynamic response of the trade balance to movements in the real exchange rate can be derived directly from (1), and does not require the knowledge of either the structural parameters of demand and supply or of exchange rate pass-through. Moreover, estimating volume and pass-through equations provide no additional insights on the central concern of the J-curve estimation.
} 
unit roots. But that procedure is liable to systematic error. In this study, we test for the presence of unit roots in all variables included in (1) by means of the Augmented Dickey-Fuller (ADF) test, allowing for drift, and including one augmenting lag of the difference. The ADF test requires for each variable under consideration the estimation of the regression equation of the form:

$$
\Delta X_{t}=C+\alpha_{1} t+\alpha_{2} X_{t-1}+\alpha_{3} \Delta X_{t-1}+\varepsilon_{t} \cdots
$$

The statistics and $p$-values of the unit root test in (2) are shown in Table 1. An examination of these results indicates that the null hypothesis of a unit root cannot be rejected for any of the variables over the observed sample period at normal significance levels. The results also indicate that stationarity can be achieved after first differencing. Therefore, trade balance, real exchange rates, and national income/output appear to be I (1), i.e., contain a stochastic trend - a feature they share with most macroeconomic time series (Campbell and Mankiw 1989).

Table 1

Unit-roots test for trade balance, real exchange rate and income

\begin{tabular}{l|c|c|c|c|c|c}
\hline \multirow{2}{*}{ country } & $\begin{array}{c}\text { Statistic } \\
\text { value }\end{array}$ & p-value & \multicolumn{2}{c|}{$\begin{array}{c}\text { Statistic } \\
\text { value }\end{array}$} & $\mathrm{p}$-value & \multicolumn{2}{c|}{$\begin{array}{c}\text { Statistic } \\
\text { value }\end{array}$} & p-value \\
\cline { 2 - 7 } & \multicolumn{3}{|c|}{$\mathrm{Y}^{*}$} & \multicolumn{2}{c|}{$\mathrm{q}$} & \multicolumn{2}{c}{$\mathrm{B}$} \\
\hline \hline U.S.A. & -3.5581 & 0.06 & -2.7373 & 0.23 & -0.7645 & 0.92 \\
Canada & -2.1415 & 0.48 & -2.6989 & 0.24 & -1.4842 & 0.76 \\
Japan & -2.7907 & 0.21 & -2.3286 & 0.40 & -3.3958 & 0.08 \\
Italy & -2.4189 & 0.35 & -2.2445 & 0.43 & -2.4709 & 0.33 \\
Germany & -2.6209 & 0.27 & -2.0726 & 0.52 & -2.9508 & 0.16 \\
France & -1.9138 & 0.59 & -2.1263 & 0.49 & -1.9415 & 0.58 \\
U.K. & -3.0455 & 0.14 & -3.5591 & 0.06 & -1.2670 & 0.83 \\
China(Y) & -1.6033 & 0.72 & & & & \\
\hline
\end{tabular}

\section{3 Tests for cointegration}

Engle and Granger (1987) have shown that when time series are characterized by nonstationarity, cointegration is a particularly appropriate statistical technique. A test for cointegration is a test of whether two or more variables share a common stochastic trend. Accordingly, testing for cointegration is a way of testing the long-term relatedness between time series that individually have a unit root. This is demonstrated in Johansen and Juselius (1990).

The cointegration test in this paper is based on the following regression which includes an ECM (Error Correction Model) term:

$$
\Delta B_{t}=C+\alpha_{1} \Delta q_{t}+\alpha_{2} Z_{t}(-1)+\alpha_{3} \Delta Y_{t}+\alpha_{4} \Delta Y_{t}^{*}+\varepsilon_{t}
$$

where $Z_{t}$ is the residual from the regression 


$$
B_{t}=u+\beta q_{t}+Z_{t}
$$

Table 2

The results of Engle and Granger cointegration test

\begin{tabular}{c|c|c|c}
\hline Countries & Null hypothesis & Statistic value & p-value \\
\hline \hline U.S.A. & $\alpha_{2}=0$ & -3.5369 & 0.4239 \\
Canada & $\alpha_{2}=0$ & -2.5247 & 0.5388 \\
Japan & $\alpha_{2}=0$ & -2.9649 & 0.3535 \\
Germany & $\alpha_{2}=0$ & -3.3112 & 0.5094 \\
France & $\alpha_{2}=0$ & -2.7726 & 0.4322 \\
Italy & $\alpha_{2}=0$ & -2.6226 & 0.7451 \\
U.K. & $\alpha_{2}=0$ & -3.0320 & 0.6159 \\
\hline
\end{tabular}

The statistical results of the cointegration test are presented in Table 2. If the variables B, q, Y, and $\mathrm{Y}^{*}$ are cointegrated, then the residual $Z_{t}$ will be integrated of the order zero, i.e., I(0) implying that the null hypothesis $a_{2}=0$ should be rejected. From Table 2 we see that p-values for $a_{2}$ are all higher than 20 per cent. Therefore, we cannot reject the null hypothesis that there is no cointegration relation among variables in all cases. Thus, these results do not indicate the presence of a cointegration vector among variables at standard significance levels. This evidence casts doubts on the existence of a stable long-run relationship between the trade balance and real exchange rate.

Table 3

Cointegration test with Error Correction Model, (Quarterly data)

\begin{tabular}{l|c|c|c}
\hline \multicolumn{1}{c|}{ Countries } & Null hypothesis & Statistic value & p-value \\
\hline \hline U.S.A. & $\alpha_{2}=0$ & $-4.8210^{*}$ & $0.0045^{*}$ \\
Canada & $\alpha_{2}=0$ & -3.2045 & 0.2156 \\
\hline
\end{tabular}

Notes: The regression result reported in this table is based on the following Model: $\Delta B_{t}=C+\alpha_{1} \Delta q_{t}+\alpha_{2} Z_{t}(-1)+\varepsilon_{t}$ where $\mathrm{Z}_{\mathrm{t}}$ is the residual from the linear regression of trade balance on foreign exchange rate: $B_{t}=u+\beta_{t} q_{t}+Z_{t}$ * significant at $1 \%$ level 
We have re-estimated eq. (3) for the United States and Canada for which quarterly trade balance data are available. As shown in Table 3, with quarterly data we find evidence of cointegration between trade balance and exchange rate only for the United States.

\subsection{Test for the significance of coefficients}

In order to test for the significance of coefficients, Eq.(1) can be transformed into a baseline equation by taking first difference of logarithms, except for $\mathrm{B}$ which is merely first-differenced:

$$
\Delta B(t)=C+\sum_{i=0}^{1}\left[B(i) \Delta Y(t-i)+Y(i) \Delta Y^{*}(t-i)\right]+\sum_{i=0}^{P} \alpha(i) \Delta q(t-i)+\mu(t) \cdots \cdots \cdots
$$

where. is the first-differencing operator and $\mu(\mathrm{t})$ is a residual. Further details on the procedure are available in Pesaran, Shin and Smith (2001). The current and last years of both domestic and foreign income is included in all regressions. Four alternatives are considered for the real exchange rate: (1) only the value for the current year; (2) the current and last year's values; (3) the current value plus two lags; and (4) the current value plus three lags. A constant is included to allow for potential deterministic drift. The null hypothesis in each case is that the current and lagged values of real exchange rate in (4) are insignificant. Four null hypotheses are tested for each country. The null hypothesis in each case is that $a(i)=0$ for all $\mathrm{i}=0,1,2,3$, against the alternative that $a(i) \neq \tilde{0}$

Table 4

Test for significance of coefficient

\begin{tabular}{|c|c|c|c|c|c|c|c|c|}
\hline \multirow{3}{*}{ Countries } & \multicolumn{2}{|c|}{$\begin{array}{l}\text { (1) Current qus no } \\
\text { q's }\end{array}$} & \multicolumn{2}{|c|}{$\begin{array}{l}\text { (2) Current + lag of q } \\
\text { vs no q's }\end{array}$} & \multicolumn{2}{|c|}{$\begin{array}{l}\text { (3) Current }+2 \text { lag of } \\
\text { qus no q's }\end{array}$} & \multicolumn{2}{|c|}{$\begin{array}{l}\text { (4) Current }+3 \text { lag of q } \\
\text { vs no q's }\end{array}$} \\
\hline & \multicolumn{2}{|c|}{ Ho: $\alpha(0)=0$} & \multicolumn{2}{|c|}{ Ho: $\alpha(0)=\alpha(1)=0$} & \multicolumn{2}{|c|}{$\begin{array}{l}\text { Ho: } \alpha(0)=\alpha(1)= \\
\alpha(2)=0\end{array}$} & \multicolumn{2}{|c|}{ Ho: $\alpha(0)=\ldots \alpha(3)=0$} \\
\hline & $\begin{array}{l}\text { Statistic } \\
\text { value }\end{array}$ & $\mathrm{p}$-value & $\begin{array}{l}\text { Statistic } \\
\text { value }\end{array}$ & $\mathrm{p}$-value & $\begin{array}{l}\text { Statistic } \\
\text { value }\end{array}$ & p-value & $\begin{array}{l}\text { Statistic } \\
\text { value }\end{array}$ & $\mathrm{p}$-value \\
\hline U.S.A. & 2.1932 & 0.138 & 2.4343 & 0.296 & 2.9343 & 0.4018 & 4.8871 & 0.2990 \\
\hline Canada & 1.726883 & 0.1888 & 5.4041 & 0.06707 & 6.2517 & $0.099 *$ & 8.866 & $0.064^{*}$ \\
\hline Japan & $0.43 \mathrm{E}-05$ & 0.998 & 1.0433 & 0.5935 & 4.2052 & 0.2401 & 10.373 & $0.0345^{* *}$ \\
\hline Germany & 0.1857 & 0.666 & 1.2438 & 0.5369 & 3.7229 & 0.2929 & 4.177 & 0.3824 \\
\hline France & 3.3862 & 0.0657 & 4.3562 & 0.113 & 4.1565 & 0.245 & 9.1067 & $0.058^{*}$ \\
\hline Italy & 0.047 & 0.82 & 0.1930 & 0.9079 & 0.0969 & 0.99 & 0.6730 & 0.954 \\
\hline U.K. & 0.4426 & 0.50 & 1.499 & 0.4724 & 2.2053 & 0.53 & 6.3104 & 0.177 \\
\hline
\end{tabular}


The baseline results are presented in Table 4. The likelihood ratios shown in the table indicate that the change in exchange rate does not significantly affect the trade balance, regardless of choice of lag lengths. At 5 per cent significance level, there is only one case, that of trade balance with Japan, in which three lags of real exchange rate are significant. At 10 per cent level of significance, there is some evidence that lags of real exchange rate are significant for trade balance with Canada.

Table 5

Test for significance of coefficients(Quarterly data)

\begin{tabular}{l|c|c|c|c|c|c}
\hline \multirow{2}{*}{ Countries } & \multicolumn{2}{|c|}{ (1)Current q vs 12 lags of q } & \multicolumn{2}{|c|}{$\begin{array}{c}\text { (2)Current }+4 \text { lags of q vs } \\
12 \text { lags of q }\end{array}$} & \multicolumn{2}{|c}{$\begin{array}{c}\text { (3)Current }+8 \text { lags of q vs } \\
12 \text { lags of q }\end{array}$} \\
\cline { 2 - 7 } & \multicolumn{2}{|c|}{ Ho: $\alpha_{1}, \alpha_{2} \ldots \alpha_{12}=0$} & \multicolumn{2}{|c|}{ Ho: $\alpha_{5}, \alpha_{6} \ldots \alpha_{12}=0$} & \multicolumn{2}{|c|}{ Ho: $\alpha_{8}, \alpha_{9} \ldots \alpha_{12}=0$} \\
\cline { 2 - 7 } & Statistic value & p-value & $\begin{array}{c}\text { Statistic } \\
\text { value }\end{array}$ & p-value & $\begin{array}{c}\text { Statistic } \\
\text { value }\end{array}$ & p-value \\
\hline U.S.A & 35.76 & $0.00035^{* *}$ & 29.33 & $0.00028^{* *}$ & 9.588 & $0.047^{*}$ \\
Canada & 20.22 & 0.063 & 16.01 & $0.042^{*}$ & 2.70 & 0.60 \\
\hline
\end{tabular}

Notes:" significant at $1 \%$ level

$*$ significant at $5 \%$ level

We have re-estimated the baseline eq (4) from quarterly data of which the results are presented in Table 5. The lagged relationships between real exchange rate and the trade balance are statistically significant, particularly for the United States. Once we employ quarterly data, there is more evidence that exchange rate changes significantly affect trade balance. While the sum of the coefficients is "correctly" signed, meaning that a depreciation eventually improves the trade balance, there is no indication of a negative short-run response which characterizes the Jcurve, even with quarterly data.3T - Statistics are presented in the parenthesis.

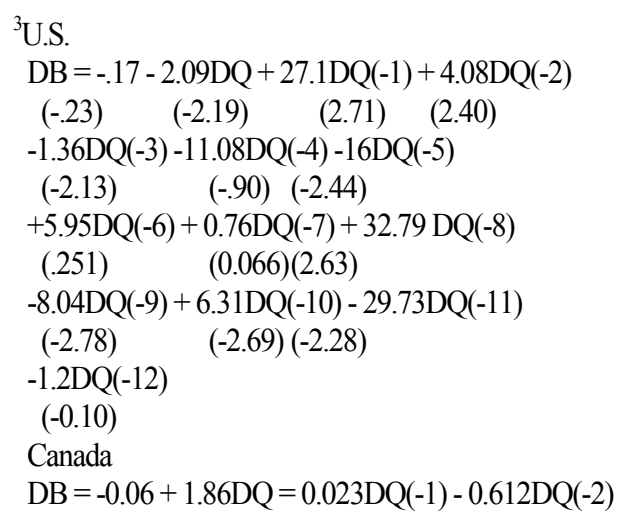


It is clear from the sign of the coefficients that no consistent adjustment pattern emerges even after twelve lags.

\section{Summary of empirical results}

To summarize, the key finding of our empirical exercise is that there is some limited evidence of an insignificant pass-through of real devaluation to trade balance, and no evidence of an initial perverse effect.

The evidence that a real devaluation positively affects trade balance becomes more pronounced for cases where quarterly observations are available, as in the case of trade balance with the United States. In order to enhance the reliability of our finding we explore further the robustness of our cointegration and baseline results. In particular, we perform a causality test to determine whether the causation runs from the real exchange rate to trade balance. ${ }^{4}$ Cointegration and causality have a well-defined statistical relationship. It is well-known (Engle and Granger 1987) that cointegration between two or more variables is sufficient for the presence of causality in, at least, one direction. This is because in order to have a long-run relationship between variables there must be some dynamic short-run interaction between them. Moreover, since causality refers to short-run predictability, the absence of cointegration does not rule out the possibility that the variables, though not cointegrated, may still have some short-run causation.

Our results on cointegration (Table 2) reveal that there is no attainable long-run relationship between the trade balance, the real exchange rate, and proxies for real income. We now perform a one-direction Granger-causality test to determine if there is a causation from the change in real exchange rate to trade balance. ${ }^{5}$ Our causality test is based on the regression:

$$
\Delta B=\alpha_{1} \Delta B(-1)+\alpha_{2} \Delta B(-2)+\alpha_{3} \Delta B(-3)+\beta_{1} \Delta q+\beta_{2} \Delta q(-2)+\beta_{4} \Delta q(-3)
$$

We test the null hypothesis (Ho: $\beta_{1}=\beta_{2}=\beta_{3}=\beta_{4}=0$ ) that the change in real exchange rate, $\mathrm{q}$, does not cause a change in the trade balance, $\mathrm{B}$.

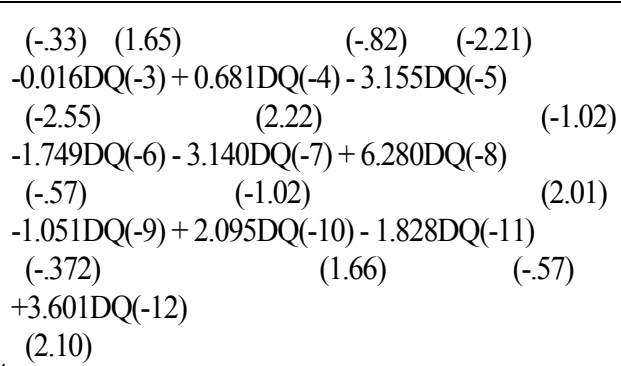

${ }^{4}$ Broadly speaking, a variable $y_{t}$ is said to be Granger-caused by another variable $x_{t}$ if current and past information on $x_{t}$ help improve the forecast of $y_{t}$.

${ }^{5}$ The opposite causation, viz., from the trade balance to the exchange rate, is not tested since it is not relevant to the Jcurve. 
Table 6

Causality Test on $\mathrm{q} \rightarrow \mathrm{B}$

\begin{tabular}{c|c|c|c}
\hline Countries & $\chi^{2}$ - statistic & P-value & Conclusion \\
\hline \hline U.S.A. & 3.8343 & 0.4289 & Accept Ho \\
Canada & 11.7532 & 0.0192 & Reject Ho \\
Japan & 3.930 & 0.4155 & Accept Ho \\
Italy & 9.0330 & 0.0602 & Accept Ho \\
Germany & 1.7062 & 0.7895 & Accept Ho \\
U.K. & 1.2262 & 0.8738 & Accept Ho \\
France & 2.3484 & 0.6719 & Accept Ho \\
\hline
\end{tabular}

Notes: $\mathrm{H}_{0}: \beta_{1}=\beta_{2}=\beta_{3}=\beta_{4}=0$

The results are presented in Table 6. As shown, we accept the null hypothesis at standard significance levels in all cases, except for Canada. This means that, with the exception of Canada, there is no causation from movements in the real exchange rate to China's trade balance with respect to any of the other G-7 countries. As such, these tests do not change the picture that emerges from cointegration tests. In fact, these results reinforce our earlier conclusion from the cointegration tests; if there is no short-run causation between variables there is no reason to expect a long-run equilibrium relationship between them.

\section{Concluding observations}

This paper has examined the hypothesis of the J-curve with data on China's bilateral trade with the G-7 countries. We have employed cointegration and causality tests to determine the long-run relatedness, as well as the short-run dynamics, between the real exchange rate and the trade balance. In addition, we employed baseline tests for the significance of coefficients. Our extensive tests have failed to discover any firm statistical evidence of the J-curve. There is some limited evidence of a positive long-run effect of exchange rate on trade balance, but there is no evidence of the negative short-run effect.

The fact that powerful econometric methodologies have failed to find reliable statistical evidence of the J-curve inevitably raises the question as to why empirical support is lacking for a proposition as well-established as the J-curve. A few comments may be made here to provoke discussion. First, there is, indeed, the possibility that the earlier evidence from conventional 
studies in favor of the J-curve may well have been spurious, since it was based on methodologies that did not deal with the problem of non-stationarity of the variables. There is now growing evidence that variables involved in the J-curve estimation have unit roots and require differencing to induce stationarity (Nelson and Plosser 1982).

Second, the assumption of a short-run inelastic response of import volumes to import prices, common in conventional studies, may itself be open to question. Descriptive analyses of devaluation episodes, particularly in the developing countries, have noted the phenomenon of "import compression" immediately following devaluation. This implies that, regardless of the numerical values of the estimated import demand elasticities, a devaluation quickly forces a reduction in the volume of imports, presumably because of a binding foreign exchange constraint. If so, there would seem to be no reason to expect the negative short-run component of the J-curve since the "perverse valuation" effect rests on the assumption that import volumes continue unchanged in the short run.

Finally, the pass-through of exchange rate changes to import prices may be sluggish or even non-existent. Foreign producers may lower their supply prices to absorb the effect of a change in the exchange rate. The squeeze on the profit margin which it entails may be part of a strategy to maintain market shares and a competitive foothold in foreign markets.

There may be other reasons why the hypothesis of the J-curve is not supported by the data. A close examination of some of the underlying assumptions with regard to elasticities and exchange rate pass-through in a detailed structural model provide additional insights.

\section{Acknowledgement}

An earlier version of this paper was presented at a faculty seminar at the East-West Center in Honolulu, Hawaii. The authors wish to thank Andy Kwan for helpful comments.

\section{References}

$595-640$.

Artus, J. 1975. The 1967 Devaluation of the Pound Sterling. IMF Staff Papers. 22.

Bahmani-Oskooee M. and A. Ratha. 2004. The J-curve: a literature survey. Applied Economics. 36. 1377-1398.

Campbell, J.Y. and N. Gregory Mankiw. 1987. Are output fluctuations transitory. Quarterly Journal of Economics. 856-880.

Cheung, Yin-Wong, Menzie D. Chinn and Eiji Fujii. 2007. The over valuation of the Renminbi undereveluation. NBER Working Paper 12850. National Bureau of Economic Research. Cambridge, Mass. 
Dornbusch, R. and Paul Krugman. 1976. Flexible exchange rates in the short run. Brookings Papers on Economic Activity. 3. 537-575.

Engle, R. F. and C.W.J. Granger. 1987. Cointegration and error correction: representation, estimation and testing. Econometrica. 55. 251-276.

Goldstein, Morris. 2007. A (lack of) progress report on China's exchange rate policies. WP 07-5, Peterson Institute of International Economics. Washington D.C.

Goldstein, Morris and Nicholas Lardy. 2006. China's exchange rate policy dilemma. American Economic Review. vol. 96. No. 2. 422-426.

Granger, C.W.J. and P. Newbold. 1974. Spurious Regression in Econometrics. Journal of Econometrics. 2. 111-120

Helkie, W.L. and P. Hooper.1987. The U.S. external deficit in the 1980s. International Finance Discussion Paper No. 304. Board of Governers. Federal Reserve System. Washington, D.C.

International Monetary Fund. 1995. Annual report of the executive board, Washington D.C.

Johansen, S. and K.Juselius. 1990. Maximum likelihood estimation and inference of cointegration with applications to demand for money. Oxford Bulletin of Economics and Statistics. 52. 169-210.

Krugman, Paul and R.E. Baldwin. 1987. The persistence of the U.S. trade deficit. Brookings Papers on Economic Activity. 1. 1-43.

Lardy, Nicholas. 1992. Foreign trade and economic reform in China, 1978-1990. Cambridge University Press.

Miles, Marc A. 1979. The effects of devaluation on the trade balance and the balance of payments: some new results. Journal of Political Economy. 87. 600-620.

Marwah, K. and L.R. Klein. 1996. Estimation of J-curves: United States and Canada. Canadian Journal of Economics. 29 523-540.

Niehans, J. 1975. Some doubts about the efficacy of monetary and fiscal policy under flexible exchange rates. Journal of International Economics. 5. 275-281.

Pesaran, M.H., Y. Shin and R.J. Smith. 2001. Bounds testing approaches to the analysis of level relationships. Journal of Applied Econometrics. 16. 289-326.

Perkins, Dwight. 1994. Completing China's move to the market. Journal of Economic Perspectives. 8. 856-880.

Rose, Andrew K. and Janet L. Yellen. 1989. Is There a J-curve?. Journal of Monetary Economics. 24. 53-68

Spitaller E. 1980. Short-run effects of exchange rate changes on terms of trade and trade balance. IMF Staff Papers. 27. 320-348.

Ueda, Kazuo. 1983. Permanent and temporary changes in the exchange rate and trade balance dynamics. Journal of International Economics. 15. 27-44.

Wei, W. 1999. An empirical study of the foreign trade balance in China. Applied Economic Letters. 6. 485-490.

Wilson, P. 2001. Exchange rates and the trade balance of dynamic Asian economies: does the J-curve exist for Singapore, Malaysia, and Korea. Open Economies Review. 12. 389-413. 
Zhang, Z. 1999. Foreign exchange rate reform, the balance of trade and economic growth: an empirical analysis for China. Journal of Economic Development. 24. 143-162. 